\title{
Investigate the Capital Structure of Facebook Based on Financial Model
}

\author{
Xiangcheng $\mathrm{He}^{1, \dagger}$ Hanyu $\mathrm{Li}^{2, \dagger}$ Xiaoxuan Peng ${ }^{3,{ }^{*} \dagger}$ Jingyi Yang ${ }^{4, \dagger}$ \\ ${ }^{1}$ Faculty of Social and Historical Sciences, University College London, London, WC1E 6BT, England \\ ${ }^{2}$ School of Economic, Nanjing University, Nanjing, Jiangsu 210000, China \\ ${ }^{3}$ School of Economic and Management, Tongji University, Shanghai, 200082, China \\ ${ }^{4}$ International Business School Suzhou, Xi'an Jiaotong Liverpool University, Suzhou, Jiangsu 215000, China \\ ${ }^{*}$ Corresponding author. Email: 1853375@tongji.edu.cn \\ These authors contributed equally.
}

\begin{abstract}
Capital structure decisions are important to the company. The capital structure is a combination of debt and equity used by a company to finance its overall operation and growth. Nowadays a company with a simple capital structure can hardly survive with the development of the market and society. As a result, it is quite significant to deeply study the structures and thus give more support to the company's development. However, the questions we solved rarely consider the impacts of frictions and taxes. Based on the Modigliani and Miller theory (MM theory) and the concept of the weighted average cost of capital (WACC), we demonstrate the conclusion that the proportion of debt in a company's capital structure makes no difference to the value of the company. This paper aims to help companies make better decisions and investments by estimating risks, returns, and the impacts from different capital structures on companies as well as the calculations of cashflows.
\end{abstract}

Keywords: Capital structure decisions, MM theory, Capital structure, WACC

\section{INTRODUCTION}

Capital structure plays a significant role in the theory of finance during the past half-century [1]. In this period, numerous research concerning capital structure have advanced theoretical models to provide a persuasive pattern for a company's capital structure. A landmark theory related to this topic is published by Modigliani and Miller in 1958, known as the MM Theory, which demonstrates the conclusion that the proportion of debt in a company's capital structure would make no difference to a firm's value. The influential theory works with the hypothesis of a perfect market - a world without taxes, perfect and credible disclosure of all information, and no transaction costs associated with raising money or going bankruptcy [2]. When applied to the real business world, the MM Theory underpinning the perfect market is not valid, giving rise to other theories like the Tradeoff Theory committed to finding a trade-off between the cost of financial distress and the tax shield benefit generated by leverage. Serving as one of the alternatives to the Trade-off Theory is the Pecking order Theory which lays its foundation on asymmetric information problems [3]. In all these structures, an unavoidable problem is the relationship between shareholders and more senior claimants-creditors, employees, and suppliers, among which catches most attention is the relationship with debtholders. Decisions benefiting shareholders might induce loss to debtholders, especially in the situation of financial distress where equity-holders prefer high risks as well as no new investment at the cost of debtholders losing their interest. Enrico and Kathryn found that by introducing leverage strategically shareholders are able to hold a large fraction of the net present value of the new investment when the firm lacks sufficient profit to pay its claim without further investment, while replacing equity with cash and simultaneously lessens the value shared by other stakeholders [4]. However, the use of debt does have its pros like mitigating the agency cost of debt caused by the separation of management from ownership and maximize the total market value of the firm for the advantage of reducing taxes.

Therefore, the necessity and benefit of debt make the topic of the capital structure an eternal one to all firms, 
resulting in a constant distinction in cashflows paid to shareholders and debtholders, respectively. Analyzing the cash flow difference enables both managers and stakeholders to make better decisions correlated to either company operation or investment plans. This paper empirically examines the aspects related to capital structure with research on the cash flow of Facebook as an example.

Based on the MM theory, this paper aims at finding the relationship between the capital structure and financing cost. Our demonstration draws support from the statistics collecting from Yahoo Finance, exhibiting the fluctuation of stock price and return by using the line chart. The conclusion is that the returns are almost between -0.04 to 0.04 , while the line fluctuates up and down around return=0. Subsequently, it is necessary for us to do some quantitative research and empirical test, we choose several states which have different proportions between equity and debt. The result shows that with the decrease of debt, the return of equity is much higher, although it is still a futile effort to reduce the cost of the company. Finally, we analyze their correlation and compare statistics in different tables.

The existing theory points out that in conditions of market economics, the changes in the capital structure could affect the cost of financing, for the cost reduced will be paid back to the investor again as compensation for higher risk. If the investors are more likely to afford a higher loss, it is reasonable for them to require more rewards when the company operates well.

In this essay, the first part briefly introduces the information about our topic, taking the example of Facebook as the center. According to the cash flows of stockholders and equity holders, we analyze the stock value and their return, helping the investors to make an appropriate decision. The second part consists of some further research. It puts forward the concept of the weighted average cost of capital (WACC) and duration. With the aid of these theories and the result of empirical tests, we conclude the factors which will affect the financing cost, such as risk, cash flow, and capital structures. Finally, we summarize both advantages and disadvantages of this paper, mapping out the sketch of the future.

There are 3 main results:

(1) In light of the MM Theory, the debt Facebook has borrowed these three years is risk-free, for the total assets is always much larger than its total liability.

(2) The company holds a low level of debt ratio in the capital structure, which makes the risk of debt relatively small.

(3) As long as the debt is risk-free, investors will not change their attitude to the company's bond and equity, leaving no influence on the cost of debt. This template, modified in MS Word 2007 and saved as a "Word 972003 Document" for the PC, provides authors with most of the formatting specifications needed for preparing electronic versions of their papers. All standard paper components have been specified for three reasons: (1) ease of use when formatting individual papers, (2) automatic compliance to electronic requirements that facilitate the concurrent or later production of electronic products, and (3) conformity of style throughout conference proceedings.

\section{BACKGROUND DESCRIPTION}

Facebook is a well-known social network service website in the United States. Recently, Facebook has undertaken a project which is worth 1 hundred million dollars, with 2 million shares and currently $\$ 50$ per share. The stock price will increase by $5 \%, 10 \%$, or $15 \%$ with equal probabilities in one year. Regardless of the taxes or other frictions, we now would like to estimate different cashflows to shareholders and debtholders to help the investors to make appropriate decisions.

Here are two-line charts (figure 1 and figure 2) drawn with the use of data collected from Jan 04, 2021 to Apr 01, 2021. 


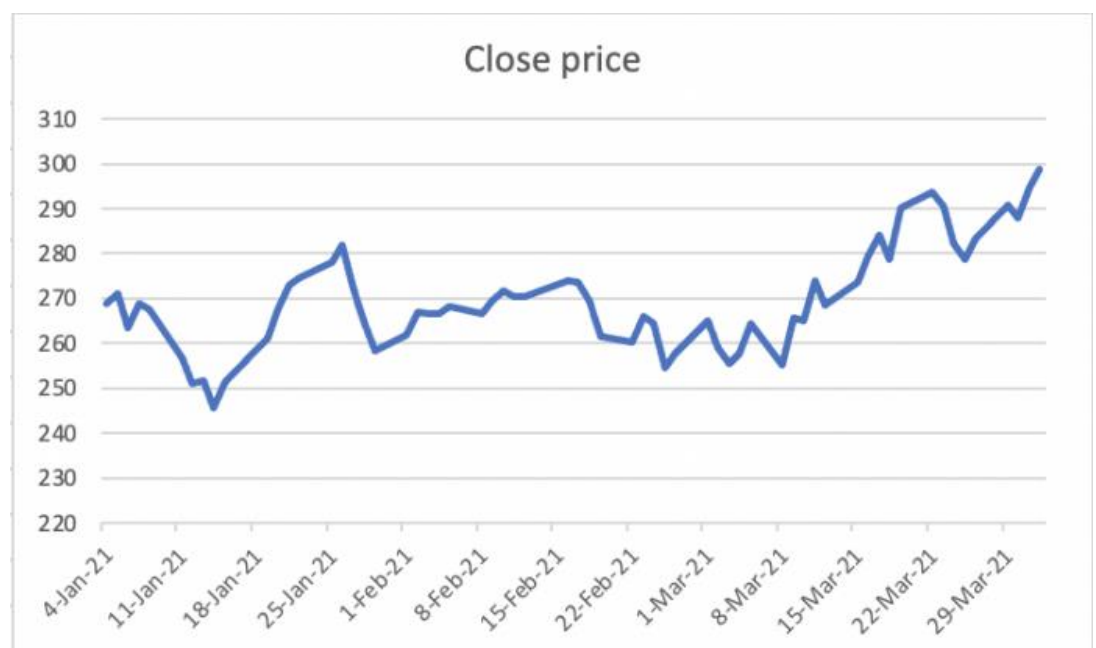

Fig. 1. Line chart of close price over time.

Fig. 1 shows that the close prices fluctuated greatly from 15-Jan-21 to nearly 25-Jan-21, and then the volatility decreased, however the line has shown an overall upward trend since 1-Feb-21 regardless of some small fluctuations. The lowest point is between 240 and 250 , while the highest point reaches almost 300 .

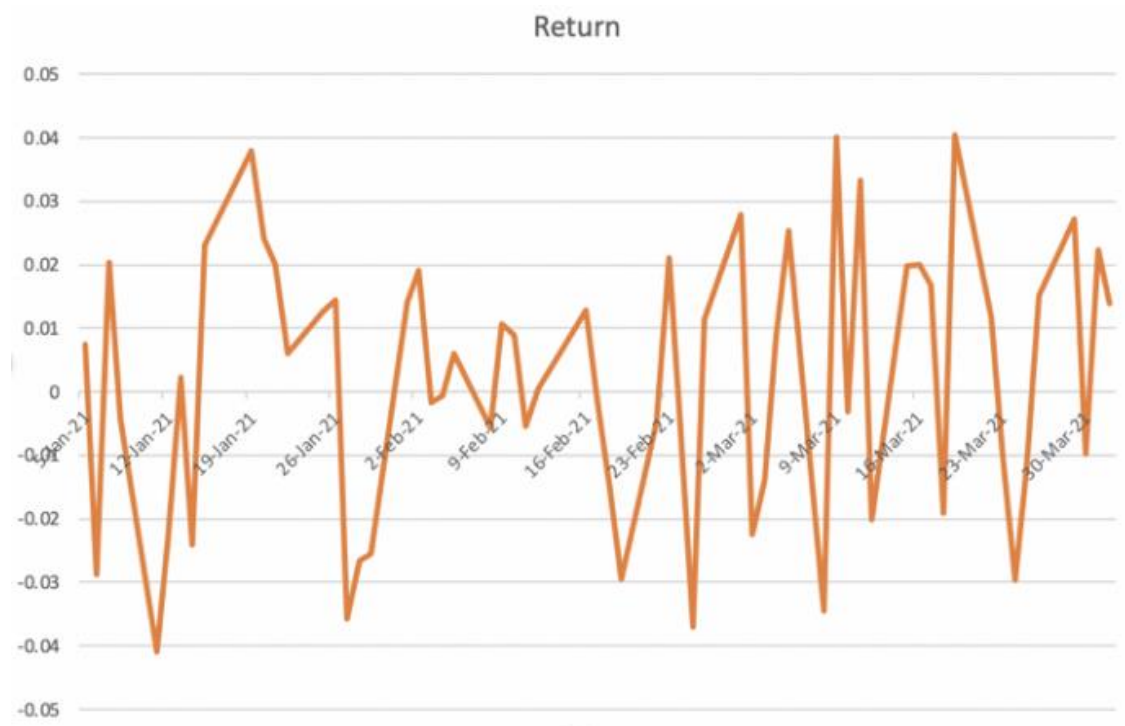

Fig. 2. Line chart of return over time

From Fig. 2, we can see that profits always come with risks, it is clear that the returns are almost between -0.04 to 0.04 , and the line fluctuates up and down around return equals to 0 .

\section{ANALYZING SPECIFIC FINANCIAL BEHAVIORS UNDER ASSUMPTIONS}

Based on some simple but reasonable assumptions, we are trying to provide methods of calculating some important financial behaviors of the Facebook company, mainly centered on the return of total capital and the cost of capital. Suppose Facebook is an all-equity financed company that has 2 million shares outstanding with a current price of $\$ 50$ per share, and in one year, the stock price will increase by $5 \% ; 10 \%$ or $15 \%$ with equal probabilities, as demonstrated graphically by Figure 3 . Then the expected rate of return to shareholders over oneyear time is equivalent to the average rate of return of the stock, which can be calculated via the function: Average rate of return of the stock $=\sum_{\mathbf{N}}(\text { rate of return })_{i} \times$ (probability $)_{\mathrm{i}}$, given $\mathrm{N}$ possible rates of return in total. So, the expected return of capital is calculated as $(5 \%+10 \%+15 \%) / 3=10 \%$. 


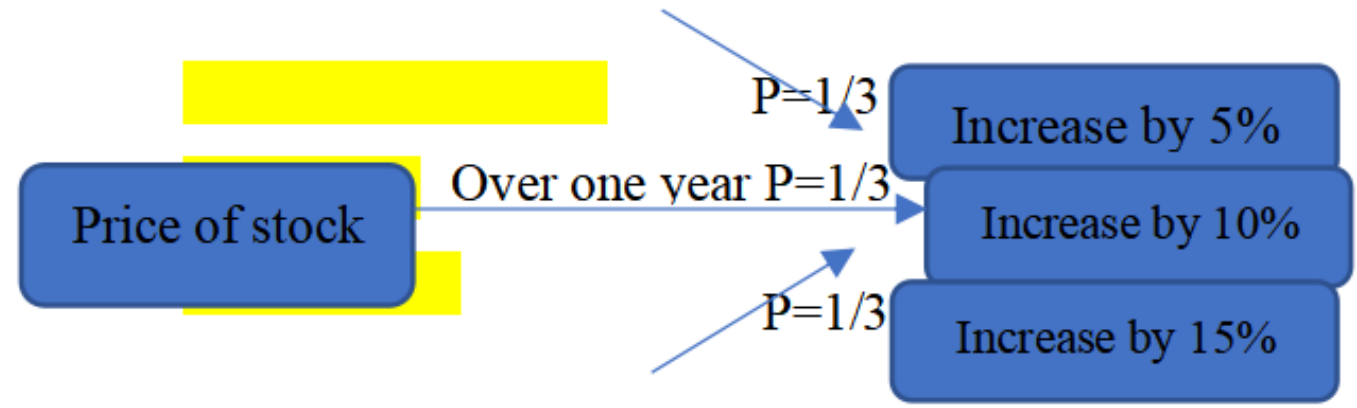

Figure 3. Suppose stock price will increase by three rates with the same probability

To calculate the cost of capital of the company, according to the function of the weighted average cost of capital (1)

$$
\text { WACC: } \left.\quad \mathbf{r}_{\mathbf{A}}=\mathbf{r}_{\mathbf{D}} \times[\mathrm{D} \div(\mathrm{D}+\mathrm{E})]+\mathbf{r}_{\mathbf{E}}[\mathrm{E} \div(\mathrm{D}+\mathrm{E})]\right]
$$

$\mathbf{r}_{\mathbf{A}}$ is the opportunity cost of capital; $\mathbf{r}_{\mathbf{D}}$ is the required rate of return on borrowings/cost of debt; $\mathbf{r}_{\mathbf{E}}$ is the required rate of return on equity/cost of equity; $[D \div(D+E)]$ is debt ratio, and $E \div(D+E)$ the equity ratio. Under the all-equity-financed assumption, the debt ratio of Facebook equals zero $(D=0)$. The cost of capital of the company $\mathbf{r}_{\mathrm{A}}$ is then $\left.\mathbf{r}_{\mathrm{D}} \times[0 \div(0+\mathrm{E})]+\mathbf{r}_{\mathrm{E}}[\mathrm{E} \div(0+\mathrm{E})]\right]$ which is equivalent to $\mathrm{rE}$ the rate of return. Since the previous calculation revealed that the expected rate of return equals $10 \%$, here $\mathbf{r}_{\mathbf{A}}$ the cost of capital will also be $10 \%$.

Though all-equity-financed assumption allows the calculation methods to be demonstrated more clearly and directly, it is not always the case in reality. Financing through all-equity has the advantages of no repayment requirement and lower bankruptcy risk, but it can also cause ownership dilution as company shares are held by various investors, and higher overall cost as equity investors demand a satisfying rate of return for their investment. In reality, Facebook is always going to finance the company through a combination of debt and equity, as Figure 4 shows the debt-equity ratio of the company in the recent decade. To further explain the importance of debt in the company's capital structure using mathematical analysis, now we suppose the senior management of the company consider replacing (today) with either $60 \%$ or $80 \%$ of the current market value of the equity by debt which costs $8 \%$ interest annually. According to equation (1), the rationale for such a step is: When more debt is used, $\mathbf{r}_{\mathbf{D}}$ is smaller since the cost of debt decreases when it is used more. Since the debt ratio is increased and an annual interest at $8 \%$ is relatively low, $\mathbf{r}_{\mathbf{A}}$ is expected to fall if $\mathbf{r}_{\mathbf{E}}$ does not increase. The company is expected to reduce cost through a step of raising debt. Even though $\mathbf{r E}_{\mathbf{E}}$ may increase following Modigliani-Miller Propositions, $\mathbf{r}_{\mathbf{A}}$ is expected to be at least unchanged. 


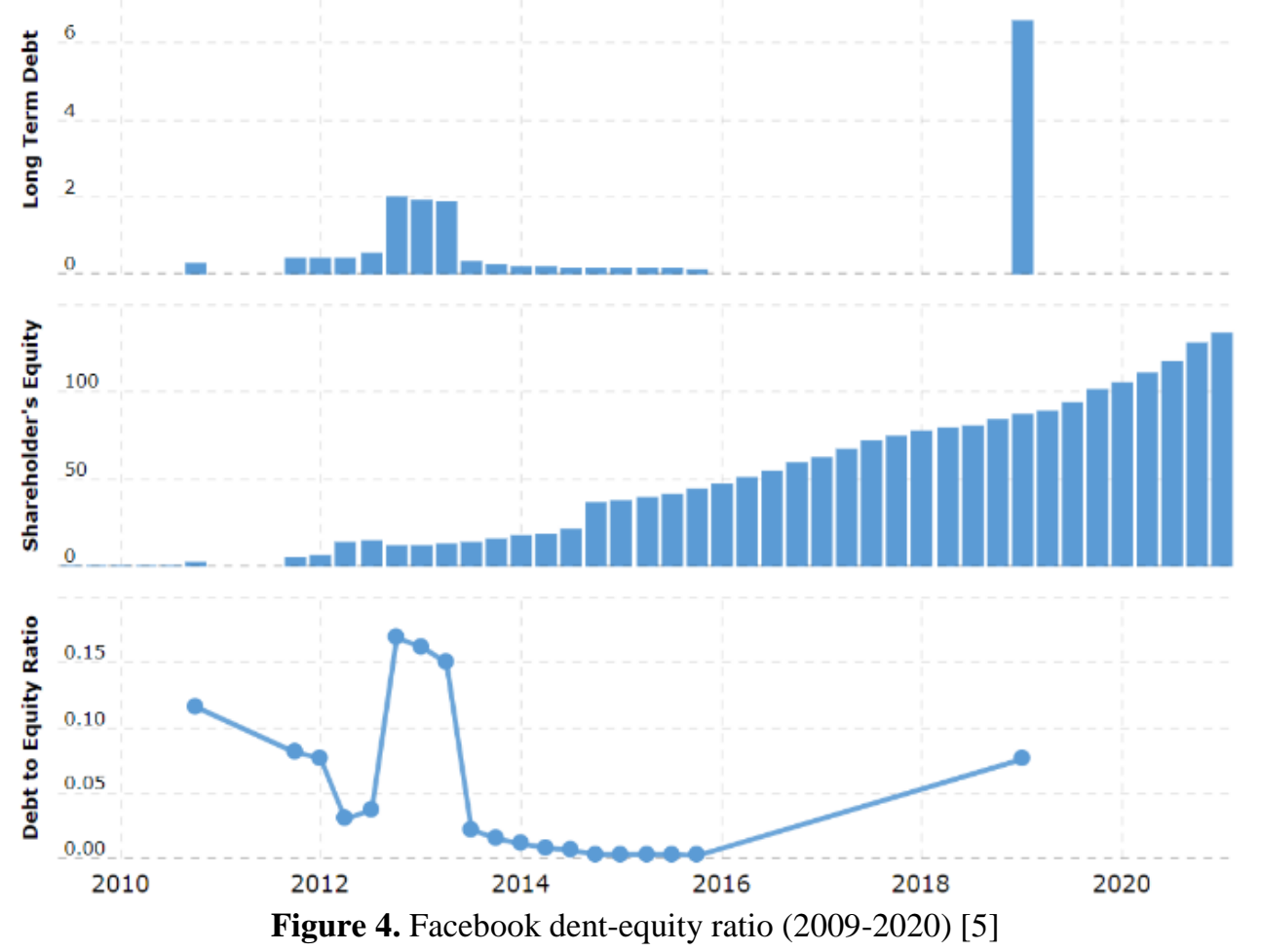

Although financial behaviors like the rate of return and capital cost can be calculated using existing functions and estimated data, most of the time, the result will not behave as we predicted. Except for technical limitations and calculation errors, one important factor that prevents us from accurately analyzing the financial status of a company is the various types of risks faced by it. The risks are usually unpredictable and impossible to be eliminated. An example of business risk faced by Facebook is that consumer tastes can change quickly in the fierce competition of technology companies, studies have shown that Twitter and Snapchat have become as frequently used among young Americans as Facebook [6]. Business risk also comes from rival competitors, though Facebook spent \$1 billion on Instagram in 2012, and purchased WhatsApp for a further $\$ 19$ billion, competing companies come in great amount and quick speed. It cannot illuminate all potential threats. In terms of political risk, Facebook has been restricted in China, Iran, North Korea, and Syria due to external political regulations, which forces it to give up a great scale of the overseas market. The financial risk appears more from the company's internal structure: Facebook received up to $97 \%$ of its revenue from advertising since the year 2016 [6]. This single reliance on advertising revenue makes Facebook fundamentally really similar to satellite firms, and the vast use of the advertisement will disturb users' experience. Market risk such as a stock market crash can also influence the financial behavior and the return of the stock of the company.

\section{THE CASHFLOWS TO SHAREHOLDERS AND DEBTHOLDERS}

In this section, to calculate the cashflows to shareholders and debt holders, we firstly introduce some theories about debt and equity, and then we analyze the question with a practical case.

\subsection{Theoretical analysis}

We know that debt and equity are two financing methods, debt has priority over equity because it is the money we borrowed from others, we need to pay it back first, as a result, it is obvious that equity value is the residual. Thus, the equity, debt, and value can be expressed as follows:

$$
\begin{aligned}
& E=V-D \\
& V_{1}=V_{0} \times\left[1+r\left(s_{i}\right)\right] \\
& D_{1}=D_{0} \times\left(1+r_{D}\right)
\end{aligned}
$$

$r_{D}$ represents the cost of debt and $D_{0}$ represents the original debt, $\mathrm{s}_{\mathrm{i}}$ represents different scenarios with the equity by debt of $60 \%$ and $80 \%$ respectively, and $V_{1}$ stands for the value of the company in one year.

\subsection{Empirical test}

With the condition that the management plans to replace either $60 \%$ or $80 \%$ of the equity by debt which 
costs $8 \%$ annually, we are now going to calculate the cashflows.

As the company has 2 million shares, and currently is $\$ 50$ per share, so the market value for the company is $2 *$ $\$ 50=1$ hundred million. The cost of debt is $8 \%$. In light of the stock price will increase by $5 \%, 10 \%$, or $15 \%$ with equal probabilities, when debt is $60 \%$, the value of the company in three scenarios can be calculated using the formula (2), the debt can be got with the use of formula (3); then we use formula (1) to find out the equity. The process of calculation is the same as the situation that the debt is $80 \%$. The results can be seen clearly in the tables below.

All values are in million \$:

Table 1. Cashflows when debt is $60 \%$

\begin{tabular}{llll}
\hline State & S1 & S2 & S3 \\
\hline V1 & 105 & 110 & 115 \\
D1 & 64.8 & 64.8 & 64.8 \\
E1 & 40.2 & 45.2 & 50.2
\end{tabular}

In table $1, \mathrm{~S} 1$ means the scenario when debt is $60 \%$ and the increasing rate of the stock price is $5 \%$, in this situation the value is 105 million dollars, the debt is 64.8 million dollars, and the equity is 40.2 million dollars. S2 represents the increasing rate of the stock price is $10 \%$, in this situation the value is 110 million dollars, the debt is 64.8 million dollars, and the equity is 45.2 million dollars $\mathrm{S} 3$ represents the increasing rate of the stock price is $15 \%$, in this situation the value is 115 million dollars, the debt is 64.8 million dollars and the equity is 50.2 million dollars.

Table 2. Cashflows when debt is $80 \%$

\begin{tabular}{llll}
\hline State & S1 & S2 & S3 \\
\hline V1 & 105 & 110 & 115 \\
D1 & 86.4 & 86.4 & 86.4 \\
E1 & 18.6 & 23.6 & 28.6
\end{tabular}

In table 2, S1 means the scenario when debt is $80 \%$ and the increasing rate of the stock price is $5 \%$, in this situation the value is 105 million dollars, the debt is 86.4 million dollars, and the equity is 18.6 million dollars. S2 represents the increasing rate of the stock price is $10 \%$, in this situation the value is 110 million dollars, the debt is 86.4 million dollars, and the equity is 23.6 million dollars S3 represents the increasing rate of the stock price is $15 \%$, in this situation the value is 115 million dollars, the debt is 86.4 million dollars and the equity is 28.6 million dollars.

\section{CAPITAL STRUCTURE'S IMPACTS}

In this section, we analyze the relationship between return and capital structure theoretically and prove it by some empirical tests.

\subsection{The influence of different capital structure}

A change in capital structure might have an impact on the return of equity and the cost of the company. Assume that the percentage of debt is $\lambda$, so the percentage of equity is $(1-\lambda)$. We know that the company has the same possibility to achieve the return of $5 \%, 10 \%$, and $15 \%$ and the return of debt is $8 \%$.

According to these assumptions, we know that the asset belonging to equity holders can be calculated by using the total asset minus the part belonging to debt holders.

$$
\text { (1) } r_{E}=[(105-100 \times \lambda \times(1+8 \%))+(110-100 \times \lambda \times(1+8 \%))+
$$

$(115-100 \times \lambda \times(1+8 \%))] \div(3 \times 100 \times(1-\lambda))$

(2) Total cost $=100 \times \lambda \times(1+8 \%)+100 \times(1-\lambda) \times r_{E}$

(3) The result of the simultaneous equations is:

Total cost $=100 \times 1.08 \times \lambda+100 \times(1-\lambda) \times(110-108 \lambda) \div(100 \times$ $(1-\lambda))=110$.

We find that no matter how the $\lambda$ change, the cost of the company is constant.

\subsection{Empirical test}

Assuming that the expected return of this company is $10 \%$, we calculate the return of equity and the cost when $\lambda$ changes. All results are presented below.

Table 3.Return and total cost with different $\lambda$

\begin{tabular}{clllll}
\hline$\lambda$ & 0.2 & 0.4 & 0.6 & 0.8 & 0.95 \\
\hline$r_{E}$ & $10.5 \%$ & $11.3 \%$ & $13 \%$ & $18 \%$ & $48 \%$ \\
$\begin{array}{c}\text { Total } \\
\text { cost }\end{array}$ & 110 & 110 & 110 & 110 & 110 \\
\hline
\end{tabular}

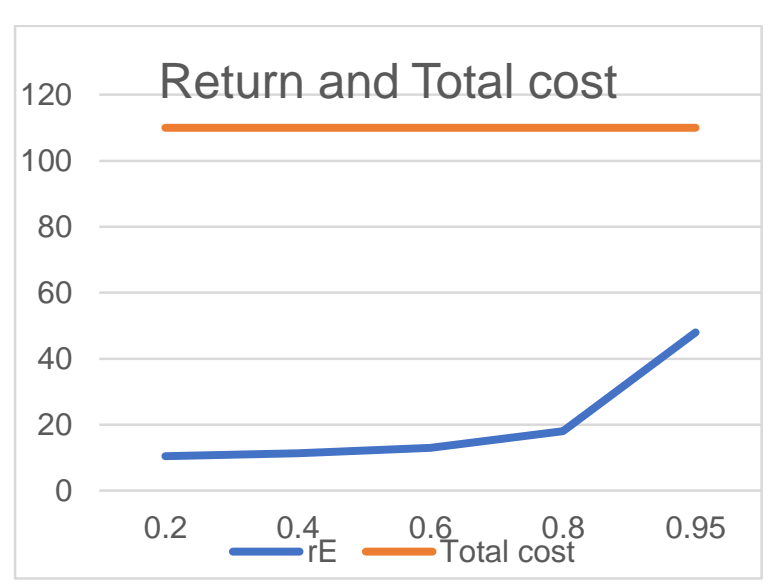

Figure 5. return and total cost 
We choose different $\lambda$ and calculate the equity return and total cost (when $\lambda=1$, it is an all-debt company). The experimental result proves our conclusion in 5.1. In addition, we find that the $r_{E}$ increase more when $\lambda$ is much closer to 1 .

\section{DISCUSSION}

Considering that distinct capital structures, which also mean different leverage ratios, can influence many aspects of a company (cashflow, return rate, etc.). As the considerable effect of the leverage ratio, we are going to discuss deeper in the question, about the risk it brings and to analyze the determinants of the leverage ratio.

\subsection{Discussion about the risk of Facebook's debt}

As an Internet company that ranks in the top 10 around the world, the great adverse effect would be exerted on the international financial market when Facebook faces bankruptcy. Therefore, analyzing the risk brought by its leverage has decisive meaning. In this section, we will try to analyze the risk of Facebook using its capital structure and leverage ratio on two occasions respectively: in the perfect market and the real competitive world.

Table 4.Excerpts from the balance sheet of Facebook from 2018-2020

\begin{tabular}{llll}
\hline Breakdown & $\mathbf{2 0 2 0}$ & $\mathbf{2 0 1 9}$ & $\mathbf{2 0 1 8}$ \\
\hline Total Current Assets & $\$ 75670000000.00$ & $\$ 66225000000.00$ & $\$ 50480000000.00$ \\
Total Non-current & $\$ 83646000000.00$ & $\$ 67151000000.00$ & $\$ 46854000000.00$ \\
Assets & $\$ 159316000000.00$ & $\$ 133376000000.00$ & $\$ 97334000000.00$ \\
Total Assets & $\$ 14981000000.00$ & $\$ 15053000000.00$ & $\$ 7017000000.00$ \\
Current Liabilities & $\$ 16045000000$ & $\$ 17269000000.00$ & $\$ 6190000000$ \\
Total Non-Current & & & \\
Liabilities Net & & & \\
Minority Interest & & $\$ 32322000000.00$ & $\$ 13207000000.00$ \\
Total Liabilities & $\$ 31026000000.00$ & $\$ 101054000000.00$ & \\
Total Capitalization & $\$ 128290000000.00$ & & \\
& & & \\
\hline
\end{tabular}

Data source: http://stockpage.10jqka.com.cn/FB/finance/

Based on table 1, which shows the capital structure of Facebook from 2018 to 2020, we could find that Facebook is always in a good financial condition in the three years. The total asset keeps increasing from $\$ 97.3$ billion in 2018 to $\$ 159.3$ billion in 2020 , while the liabilities experienced a dramatic increase from 2018 to 2019 of about $\$ 20$ billion, which means Facebook changed its capital structure that year.

To analyze Facebook's financial risk, let us start with the simplest scenario - a perfect world created by Miller and Modigliani. In the Modigliani-Miller Propositions, the market is unaffected by taxes, transaction costs, or any other market imperfections. Moreover, they assumed that the bond as well as the stock price would not be affected by the increase in leverage, leading to no change in the total market value of the company. As a result, the risk of debt is only related to the amount of debt compared with the total value of the company. (Without imperfections the money Facebook can pay back to debtholders is its present market value, as all the assets can be changed into cash in the price of its market value.) Thus, in the light of the MM Theory, the debt Facebook has borrowed these three years is risk-free, for the total assets are always much larger than its total liability. (from Table 4)

Nevertheless, the reality is full of imperfections. More problems come out not only in the imperfections mentioned above but more of the liquidity of assets as well its proportion in the whole assets. When assessing Facebook's ability in paying back liabilities, current assets with more realizability is an efficient indicator. From Table 4 we can tell that the total current assets surpass the total liabilities during the period, which indicates that even without MM's assumption, the debt Facebook borrowed is still risk-free. 
Table 5.the leverage ratio of Facebook from 2018 to 2020

\begin{tabular}{llll}
\hline Year & $\mathbf{2 0 2 0}$ & $\mathbf{2 0 1 9}$ & $\mathbf{2 0 1 8}$ \\
\hline $\begin{array}{l}\text { Leverage } \\
\text { ratio }\end{array}$ & 0.24 & 0.32 & 0.16 \\
\hline
\end{tabular}

Data source:

http://stockpage.10jqka.com.cn/FB/finance/

Table 5 illustrates the leverage ratio in the following 3 years from 2018. The leverage ratio doubled in 2019, followed by a decrease to 0.24 in 2020 .

According to the conclusion from table 4, which is based on another assumption-little volatility in the market price of bond and equity, the leverage of Facebook in the three years was risk-free. In MM's world, the assumption above is true for they eliminated all influence factors. Thus, the cost of debt, the debtholders' claim on part of the cash flow, is constant because they are indifferent with all degrees of leverage on the condition that the company is capable of fully paying the liabilities. In other words, if the debt is riskfree, investors will not change their attitude to Facebook's bond and equity, leaving no influence on the cost of debt.

In the competitive market, Facebook's current leverage ratio will make no big influence as well. When we go back to the real world, investors of listed companies, especially stars like Facebook, are quite sensitive to any small changes in the capital structure and will adjust their portfolio to their favor in a timely manner. Therefore, to raise the same amount of capital, companies are forced to change their effective rate on debt regarding the market trend. Within a moderate range of leverage, no big distinction will be seen in the cost of debt because when borrowing in a safe sone, different capital structures followed by distinct levels of leverage will be preferred by investors with various preferences. From Table 5 we can conclude that Facebook holds a low level of debt ratio in the capital structure, which makes the risk of debt relatively small.

\subsection{Discussion on determinants of optimal leverage ratio}

In this section, we are talking about the possible determinants of a company's leverage ratio like various industries, the risk of bankruptcy, and other influence factors. Some theories related to the determinants of the leverage ratio will also be presented below.

Different industries take advantage of the leverage ratio differently. Therefore, the degree of leverage varies considerably by business sectors as well as industry. Below are two lists of the leverage ratio in various sectors and typically in the industry of Facebook, Internet Service and Social Media, in a positive sequence alignment. Both the tables are published by CSIMarket in 2021.

In many industry sectors, companies are liable to have a higher degree of leverage. Capital-intensive industries, which need lots of investment in infrastructures or services, rely more on debt as a stable resource of capital. From table 6 it is clearly shown that technology companies operate at a nearly double degree of leverage as those who sell capital goods. Facebook is a company that is more like a conjunction of the Service and Technology sectors, whose leverage ratio both close to 2 . Table 6 is an average level of a large classification. More specialized data are illustrated in table 7 , which shows a more suitable category for Facebook. Concerning the leverage ratio of Facebook in table 2 and information provided by table 7, we can conclude that Facebook has a relatively low leverage ratio compared to the average level in its industry (only 0.24 compared to an average 0.92 ). This means less risk in corporate operation, while might also induce low efficiency in financing.

Table 6.the leverage ratio in different sectors in 2020

\begin{tabular}{lll}
\hline Ranking & $\begin{array}{l}\text { Leverage Ratio } \\
\text { Ranking by Sector }\end{array}$ & Ratio \\
\hline 1 & Capital Goods & 1.33 \\
2 & Basic Materials & 1.66 \\
3 & Consumer & 1.77 \\
4 & Discretionary & \\
5 & Healthcare & 1.92 \\
6 & Services & 1.95 \\
7 & Consumer Non- & 2.00 \\
& Cyclical & 2.08 \\
\hline
\end{tabular}

Data source:

https://csimarket.com/screening/index.php?s=le\&pageI= $1 \&$ fis=\#tableind

Table 7.leverage ratio best-performing Industry ranking in 2020

Ranking Industries Ranking Within the Sector Ratio

$\begin{array}{llll}22 & \begin{array}{l}\text { Internet Services } \\ \text { \& Social Media }\end{array} & 22 & 0.92\end{array}$

\section{Data source:}

https://csimarket.com/screening/index.php?s=le\&pageI= $1 \&$ fis=\#tableind

However, an optimal leverage ratio is not only determined by its business sector and a higher leverage ratio does not mean more benefits to the company in all 
scenarios. Bankruptcy is one of the most transparent consequences to heavily levered firms. Examples include R.H. Macy, Trans World Airlines, Great Atlantic \& Pacific Tea Co. (A\&P), and Midwest Generation[7]. Moreover, aggressive use of leverage on a large scale might result in a financial crisis like in 2008

Except for the risk of bankruptcy above, other determinants in leverage ratio include issuance costs, tax benefits on debt, and earnings ratio, determine the optimal choice of leverage and maturity are investigated further in some theories.

One of the most known is the Trade-off Theory, which claims that firms seek debt levels that balance the tax advantages of additional debt against the costs of possible financial distress[8]. Its counterparts include The Pecking Order Theory, which discusses further in another aspect. It focuses on firms that lack sufficient internal cashflows and fund capital expenditure more by borrowing than issuing equity. Another theory investigating in mature firms is called the Free Cash Flow Theory[9]. It discovers the increase in value might be brought by dangerously high debt levels, despite the threat of financial distress. However, the theory is suitable to those mature companies when their operating cash flow considerably surpasses their investment opportunities. More models might be invented in the future as finance is more advanced along with more detailed financial conditions. Scholars will not stop in finding an optimal leverage ratio for various industries as well as the determinants of it.

\section{CONCLUSION}

The capital structure is the particular combination of debt and equity used by a company to finance its overall operation and growth. Nowadays a company with a simple capital structure can hardly survive with the development of the market and society. So, it is vital for a company to choose an appropriate one. Facebook is a world-famous company. We put it as a typical example to analyze the relationship between capital structure and financing cost.

Based on the MM Theory, we first analyzed different risks a company might be exposed to and their influence factors, especially against the backdrop of the Corona pandemic. Second, with the assumption of different capital structures, we calculate the return to both debtholders and stockholders respectively using the WACC and comparing the present value under each structure with diverse growth opportunities. Then we further discuss different impacts that capital structures imposed on a company and a suitable leverage ratio particularly for internet companies, supported by the MM Theory.

In this article, the shortcoming is that the capital cost reduction does not work out as expected since in equilibrium the shareholders' return will increase greatly as to exactly offset the positive substitution effects. Also, due to the existence of frictions and the asymmetry of investors' information, debt structures will change, as a result of which there would be implications for the share price. In this paper, we only discuss the situation using the MM model that the company does not need to pay taxes. In the future, we would further explore the situation with the consideration of frictions and taxes to obtain findings of the effects on stock price and cash flows.

\section{REFERENCES}

[1]. Bradley, M., Jarrell, G., \& Kim, E. (1984). On the Existence of an Optimal Capital Structure: Theory and Evidence. The Journal of Finance, 39(3), 857878.

[2]. Chen, J. J. (2004). Determinants of capital structure of Chinese-listed companies. Journal of Business research, 57(12), 1341-1351.

[3]. Becker, B., \& Strömberg, P. (2012). Fiduciary duties and equity-debtholder conflicts. The Review of Financial Studies, 25(6), 1931-1969.

[4]. Perotti, E. C., \& Spier, K. E. (1993). Capital structure as a bargaining tool: The role of leverage in contract renegotiation. The American Economic Review, 1131-1141.

[5]. Facebook Debt to Equity Ratio 2009-2020. Macrotrends,

www.macrotrends.net/stocks/charts/FB/facebook/d ebt-equity-ratio.

[6]. Ross, Sean. The Big Risks of Investing in Facebook Stock. Investopedia, Dotdash Publishing Family, 14 May 2019.

[7]. Adkins, Troy. Optimal Use of Financial Leverage in a Corporate Capital Structure, 2021.

[8]. Campbell, D. E., \& Kelly, J. S. (1994). Trade-off theory. The American Economic Review, 84(2), 422-426.

[9]. Frank, M. Z., \& Goyal, V. K. (2008). Trade-off and pecking order theories of debt. Handbook of empirical corporate finance, 135-202. 